\title{
COMPARATIVE ANALYSIS OF THE STATE OF PRD- AND ANTIOXIDANT SYSTEMS IN CHILDREN UNDER THE INFLUENCE OF STRESS FACTORS OF RADIATION AND PSYCHOGENIC ORIGIN
}

Stepanova Ye.I., Kolpakov I.Ye., Poznysh V.A., Vdovenko V.Yu., Zygalo V.M., Alekhina S.M. ПОРІВНЯЛЬНИЙ АНАЛЗ СТАНУ ПРО- ТА АНТИОКСИДАНТНОї СИСТЕМ У ДІТЕЙ ЗА ДІЇ СТРЕСОВИХ ЧИННИКІВ РАДІАЦЙНОГО ТА ПСИХОГЕННОГО ПОКОДЖЕННЯ

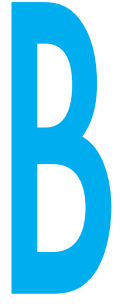

СТЕПАНОВА $€ . І .$, КОЛПАКОВ І.Є., ПОЗНИШ В.А., ВДОВЕНКО В.Ю., ЗИГАЛО В.М., АЛЬОХІНА С.М. ДУ «Національний науковий центр радіаційної медицини Національної академії медичних наук України», м. Київ, Україна

Ключові слова: діти, радіоактивно забруднені території, зона збройного конфлікту, перекисне окислення ліпідів, антиоксидантний захист. наслідок екологічних та соціальних катастроф складаються ситуації, які призводять до зниження стресостійкості дітей, обумовлюють порушення психоемоційного стану, викликають розвиток функціональних розладів з боку різних органів і систем 3 наступною трансформацією їх у хронічну соматичну та психосоматичну патологію. Патогенез усіх цих несприятливих зрушень $\epsilon$ спільним для дітей-мешканців радіоактивно забруднених територій і дітей, переміщених із зони бойових дій на південному сході України. Його можна уявити у вигляді єдиного процесу, «пусковим механізмом» якого $€$ стресовий вплив на організм радіаційного та/або психогенного чинників, а наслідки визначаються ступенем виразності різних типів компенсаторних реакцій, обумовлених певними генетичними особливостями організму $[1,2]$.

Основною ланкою вільнорадикального окислення в умовах розвитку патологічних станів $€$ утворення активних форм кисню, які під час взаємодії з ліпідами біологічних мембран створюють активні радикали та перекиси у надлишковій кількості. Надмірна активація вільнорадикального окислення, що ініціює утворення первинних радикалів (оксиду азоту та супероксиданіон-радикалу) призводить до пошкодження структурних компонентів біологічних мембран і ферментних систем клітин. Процес поглиблюється за рахунок інтенсифікації перекисного окислення ліпідів (ПОЛ), що супроводжується появою первинних (дієнових сполук) та вторинних сполук (малоновий
СРАВНИТЕЛЬНЫЙ АНАЛИЗ СОСТОЯНИЯ ПРОИ АНТИОКСИДАНТНОЙ СИСТЕМ У ДЕТЕЙ ПРИ ВОЗДЕЙСТВИИ СТРЕССОВЫХ ФАКТОРОВ РАДИАЦИОННОГО И ПСИХОГЕННОГО ПРОИСХОЖДЕНИЯ

Степанова Е.И., Колпаков И.Е., Позныш В.А., Вдовенко В.Ю., Зыгало В.М., Алехина С.М. ГУ «Национальный научный центр радиационной медицины Национальной академии медицинских наук Украины», г. Киев, Украина

Цель работы. Оценка процессов перекисного окисления липидов и антиоксидантной защиты у детей при воздействии стрессовых факторов радиационного и психогенного происхождения. Материалы и методы. Обследованы дети школьного возраста - жители радиоактивно загрязненных территорий (РЗТ) и детипереселенцы из зоны вооруженного конфликта, подвергшиеся воздействию стрессовых факторов. Для определения признаков оксидативного стресса проводили исследования конечных продуктов перекисного окисления липидов (ПОЛ), реагирующих с тиобарбитуровой кислотой (малонового диальдегида - МДА), ферментов-антиоксидантов - каталазы, супероксиддисмутазы, глутатионпероксидазы, глутатионтрансферазы.

Результаты и выводы. У детей-жителей РЗТ и детей, перемещенных из зоны вооруженного конфликта, имел место дисбаланс в системе ПОЛ - антиоксидантной защиты, более выраженный у детей-жителей РЗТ, у которых по сравнению с контролем наблюдалось повышение содержания в сыворотке крови конечных продуктов ПОЛ, реагирующих с тиобарбитуровой кислотой; изменения активности ферментов-антиоксидантов: снижение активности супероксиддисмутазы, повышение активности каталазы, глутатионпероксидазы, глутатионтрансферазы. У детей-переселенцев из зоны вооруженного конфликта изменения показателей интенсивности процессов ПОЛ и активности ферментов системы антиоксидантной защиты носили однонаправленный характер, но были менее выражены.

Ключевые слова: дети, радиоактивно загрязненные территории, зона вооруженного конфликта, перекисное окисление липидов, антиоксидантная защита.

(С) Степанова Є.І., Колпаков І.Є., Позниш В.А., Вдовенко В.Ю., Зигало В.М., Альохіна С.M. СТАТTЯ, 2019. 
COMPARATIVE ANALYSIS OF THE STATE OF PROAND ANTIOXIDANT SYSTEMS IN CHILDREN UNDER THE INFLUENCE OF STRESS FACTORS OF RADIATION AND PSYCHOGENIC ORIGIN Stepanova Ye.I., Kolpakov I.Ye., Poznysh V.A., Vdovenko V.Yu., Zygalo V.M., Alekhina S.M. State Institution «National Research Center for Radiation Medicine of the National Academy of Medical Sciences of Ukraine», Kyiv, Ukraine

Objective: We evaluated the processes of lipid peroxidation and antioxidant protection in children under the influence of stress factors of radiation and psychogenic origin.

Materials and methods: The children of school age - residents of radioactive contaminated territories $(R C T)$ and children-forced migrants from the armed conflict zone exposed to stress factors, were examined. The final products of lipid peroxidation $(L P O)$ reacting with thiobarbituric acid (malondialdehyde - MDA), enzymes-antioxidants - catalase, superoxide dismutase, glutathione peroxidase, glutathione transferase were studied by us to determine the signs of oxidative stress.

Results and conclusions: In children-residents of $R C T$ and children-displaced from the zone of armed conflict, the imbalance in the LPO system was revealed, an antioxidant protection is morepronounced among children-residents of RCT. An increase in the serum content of end-products of lipid peroxidation reacting with thiobarbituric acid was observed in children-residents of RCT compared with the control; changes in the activity of antioxidant enzymes such as a decrease in the activity of superoxide dismutase, an increase in catalase activity, glutathione peroxidase, glutathione transferase were observed. In childrenmigrants from the zone of armed conflict, changes in indicators of the intensity of LPO processes and the activity of enzymes in the antioxidant defense system were unidirectional, but were less pronounced.

Keywords: children, radioactive contaminated territories, zone of armed conflict, lipid peroxidation, antioxidant protection. диальдегід) [3, 4].

Відомо, що негативній дії вільних радикалів і перекисних сполук запобігає багатокомпонентна система антиоксидантного захисту (АОЗ), одне з провідних місць в якій посідає система глутатіону, яка внутрішньоклітинно забезпечує детоксикацію та інактивацію ушкоджувальних чинників. До складу системи глутатіону входять відновлений глутатіон і ферменти, які забезпечують регенерацію відновленого глутатіону із окисненої форми. До цих ферментів належать глутатіонпероксидаза, глутатіонредуктаза та глутатіонтрансфераза $[5,6]$.

Багатокомпонентний АОЗ в організмі забезпечується ензимними антиоксидантними механізмами, ендо- та екзогенними антиоксидантами неферментативної природи, які 3 ними синергійно взаємодіють. Найважливішу роль відіграють ензимні механізми АО3, що здійснюються групою ферментів - супероксиддисмутазою, каталазою, глутатіонпероксидазою, глутатіонредуктазою, глутатіонтрансферазою, церулоплазміном тощо. Для оцінки функціонального стану системи антиоксидантного захисту доцільним є визначення основних з цих показників $[5,6]$.

Мета дослідження. Оцінка процесів перекисного окислення ліпідів та антиоксидантного захисту у дітей за дії стресових чинників радіаційного та психогенного походження

Матеріали та методи дослідження. Обстежено 99 дітей шкільного віку (від 10 до 17 років), які перебували на стаціонарному лікуванні у клініці ННЦРМ.

Серед них виділено групу I 59 дітей-мешканців радіоактивно забруднених територій (РЗТ). Обстежені діти постійно (з моменту народження) проживали на радіоактивно забруднених територіях Народицького, Овруцького, Коростенського та Олевського районів Житомирської області зі щільністю забруднення ґрунтів ${ }^{137} \mathrm{Cs}$ від 10 кБк/м² до 555 $\mathrm{K} Б \mathrm{~K} / \mathrm{M}^{2}$.

Вміст ${ }^{137} \mathrm{Cs}$ в організмі дітей визначали за допомогою лічильника випромінювання людини (ЛВЛ) Скриннер-3М виробництва Інституту екології людини

у дітей-мешканців радіоактивно забруднених терито-

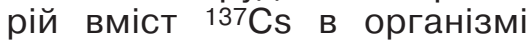
коливався у межах 185-8806 Бк.

II група - 40 дітей, переміщених із зони бойових дій на південному сході України. За даними ЛВЛ, у дітей, переміщених із зони збройного конфлікту, вмісту ${ }^{137} \mathrm{Cs}$ не зафіксовано.

У дітей обох груп виявлено функціональні розлади з боку шлунково-кишкового тракту, які супроводжувалися вегета- тивною дисфункцією. Із вогнищ хронічної інфекції виявлялися хронічний компенсований тонзиліт та карієс зубів.

Частота виявленої патології у дітей I та II груп суттєво не відрізнялася.

В якості контролю (III група) використано результати обстеження 49 дітей, які не зазнавали дії стресових чинників радіаційного та/або психогенного походження. За віком, статтю та станом здоров'я вони не відрізнялися від дітей основних груп.

Для визначення ознак оксидативного стресу та балансу у системі ПОЛ-АОЗ проведено такі дослідження

1. Визначення вмісту продуктів ПОЛ, що реагують з тіобарбітуровою кислотою (малонового диальдегіду - МДА), у сироватці крови.

Принцип методу. За високої температури у кислому середовищі малоновий діальдегід (МДА) 3 2-тіобарбітуровою кислотою (ТБК) утворює стійкий триметиловий комплекс, який забарвлюється у бузковий колір [7].

Реактиви: $1 \%$ розчин $\mathrm{H}_{3} \mathrm{PO}_{4}$, $1 \%$ водний розчин ТБК $(\mathrm{pH}=7,0)$, дистильована вода.

Хід визначення. У дослідну пробу до 0,2 мл сироватки крови додавали 2 мл 1\% розчину $\mathrm{H}_{3} \mathrm{PO}_{4}, 0,6$ мл 1\% водного розчину ТБК.

До контрольної проби замість сироватки крови вносили 0,2 мл дистильованої води. 
2 мл $1 \mathrm{~N} \mathrm{HCl}$ на ізотонічному розчині натрію хлориду. Оптичну густину дослідної проби порівняно 3 дистильованою водою вимірюють на спектрофотометрі за довжини хвилі 530 нм. Концентрацію гемоглобіну можна визначити будь-яким стандартним лабораторним методом.

Хід визначення. До 2 мл розчину «Б» додають 0,4 мл хлороформу та 0,2 мл етанолу, енергійно струшують протягом 5 хв. та центрифугують 10 хв. 3 швидкістю обертання 4000 об./Хв.

0,1 мл отриманого центрифугату вносять у контрольні та дослідні пробірки з інкубаційною сумішшю у складі 2 мл 4\% молібдату амонію, 0,9 мл дистильованої води, 1 мл 0,03\% $\mathrm{H}_{2} \mathrm{O}_{2}, 2$ мл 4\% молібдату.

Контрольну та дослідні проби інкубують на водяній бані за температури 22॰C протягом 10 хв. Після інкубації для зупинення реакції до дослідної проби додають 2 мл 4\% молібдату амонію.

Оптичну густину дослідної проби порівняно з контрольною вимірюють на спектрофотометрі за довжини хвилі 410 нм.

Активність КАТ (A) розраховують за формулою 2:

$$
\mathrm{A}=\frac{\mathrm{E}_{\mathrm{K}}-\mathrm{E}_{\mathrm{Z}} \times 1000 \times 2 \times 1,1 \times 10}{\mathrm{E}_{\mathrm{H} 2 \mathrm{O} 2} \times \mathrm{Hb} \times 10}, \text { мкМоль } / \text { мгНb, (2) }
$$
де $T$ - відсото

де $E_{\kappa}$ - екстинкція контрольної проби; $E_{д}$ - екстинкція дослідної проби; 1000 - коефіцієнт перерахунку у мкM $\mathrm{H}_{2} \mathrm{O}_{2} ; 2 ; 1,1$; 10 - коефіцієнти розведення проби; $E_{\mathrm{H}_{2} \mathrm{O} 2}$ - екстинкція $1 \mathrm{mM}$ розчину $\mathrm{H}_{2} \mathrm{O}_{2}$ з молярною концентрацією 2200 мМоль $^{-1} \times \mathrm{CM}^{-1}$; Hb - вміст гемоглобіну у пробі, мг/мл; 10 - термін інкубації, хв.

3. Визначення активності суперокисиддисмутази в еритроцитах.

Принцип методу. Метод ґрунтується на здатності супероксиддисмутази (СОД) гальмувати реакцію аутоокислення адреналіну за $\mathrm{pH}=10,2$ [7].

Реактиви: 0,15 М карбонатний буфер (pH = 10,2) з 3×10-4 М ЕДТА, хлороформ, 96\% етанол, 0,1\% адреналін, дистильована вода.

Приготування гемолізату. Гемолізат готується таким самее чином, як і під час визначення каталази. Перед окислення адреналіну СОД, \%; $E$

дослідженням визначають вміст гемоглобіну у гемолізагемолізату у пробірку додають ,4 мл хлороформу, 0,2 мл . Центрифугують протягом 10 хв з швидкістю обертання 4000 об./Хв.

5 мл отриманого центрифувосят у пробірки 3 інку баційною сумішшю у складі мл карбонатного буферу $\mathrm{pH}=10,2)$ та 0,1 мл адреналіну. До контрольної проби замість гемолізату додають 0,5 мл дистильованої води.

Оптичну густину вимірюють на спектрофотометрі з термостатованою кюветою за температури $30^{\circ} \mathrm{C} 3$ довжиною хвилі 340 нм протягом 5 хв. щохвилини

Активність СОД (А) розраховують послідовно за формулами 3-6:

$$
\Delta E=E_{К}-E_{Д},(3)
$$

де $E$ - різниця екстинкції контрольної та дослідної проб; $\mathrm{E}_{K}$ екстинкція контрольної проби; $E_{\text {д }}$ - екстинкція дослідної проби. $\mathrm{T} \%=\frac{\Delta \mathrm{E}}{\mathrm{E}_{\mathrm{K}}} \times 100 \%,(4)$ різниця екстинкції контрольної та дослідної проб; $E_{k}-$ екстинкція контрольної проби.

$$
I=\frac{T \%}{100-T \%}
$$

де I - відсоткове інгібування аутоокислення адреналіну СОД, \%; T - відсоток інгібування аутоокислення адреналіну СОД, \%.

$\mathrm{A}=\frac{\mathrm{I} \times 2 \times 1,1}{1 \mathrm{Hb}}$ ум.од./мгНb, (6)

де $A$ - активність СОД; I - відсоткове інгібування аутоокислення адреналіну СОД, \%; $H b$ - вміст гемоглобіну у пробі, мг/мл; 2 - кількість гемолізату у пробі, мл; 1,1 - коефіцієнт розведення проби.

Для розрахунку беруть дані екстинкцій дослідної проби між 3 та 4 хвилинами.

4. Визначення активності глутатіонпероксидази в еритроцитах.
Визначають вміст гемоглобіну: до 2 мл розчину «Б» додають 
Глутатіонпероксидаза каталізує окислювально-відновлювальну реакцію між відновленим глутатіоном та органічними перекисами (гідроперекиси жирних кислот, перекиси).

Принцип методу: про активність ферменту свідчить накопичення глутатіону окисленого за певний проміжок часу, концентрація якого визначається спектрофотометрично [7].

Реактиви: 0,3 М фосфатний буфер ( $\mathrm{pH}=7,4) ; 12$ мМ азид натрію; 6 мМ ЕДТА (трилон Б); 2,5 мМ глутатіон відновлений; 1,8 мМ перекис водню; 10\% розчин трихлороцтової кислоти; ізотонічний розчин натрію хлориду; дистильована вода

Підготування гемолізату: 0,5 мл цільної крови тричі промивають 10 мл ізотонічного розчину натрію хлориду та центрифугують протягом 10 хв. $з$ швидкістю обертання 3000 об./хв. Отримують еритроцитарну масу. Для дослідження використовують еритроцитарну масу, розведену дистильованою водою у співвідношенні 1:40.

Хід визначення. 0,2 мл гемолізату вносять до дослідної проби з інкубаційною сумішшю у такому складі: 1 мл 0,3 М фосфатний буфер $(\mathrm{pH}=7,4) 3$ 12 мМ азид натрію та 6 мМ ЕДТА; 0,5 мл глутатіон відновлений.

До контрольної проби замість гемолізату додають 0,2 мл дистильованої води.

Для початку реакції до інкубованої суміші додають 0,5 мл перекису водню. Контрольну та дослідну проби інкубують на водяній бані за температури $22^{\circ} \mathrm{C}$ протягом 2 хв. Зупиняють реакцію додаванням 1 мл 10\% розчину трихлороцтової кислоти та центрифугують протягом 15 хв. 3 швидкістю обертання 3000 об./хв.

Оптичну густину центрифугату дослідної проби порівняно 3 контрольною вимірюють на спектрофотометрі з довжиною хвилі 260 нм.

Активність ферменту глутатіонпероксидази (A) розраховують за формулою 7:

$\mathrm{A}=\frac{\mathrm{E}_{\mathrm{K}} \times \mathrm{V}_{\text {д }}}{\mathrm{K} \times \mathrm{Hb}}$, мМоль $/$ мгНb $\times$ хв., (7)

де $E_{д}-$ екстинкція дослідної проби; $V_{\text {д }}$ - об'єм дослідної проби, мл; K - коефіцієнт молярної екстинкції глутатіону окисленого, 1144 мМоль ${ }^{-1} \mathrm{xcM}^{-1}$; Нb - концентрація гемоглобіну у гемолізаті, мг/мл.

5. Визначення активності глутатіон-S-трансферази.

Принцип методу. Визначення активності цього ферменту ґрунтується на оцінці швидкості ферментативного утворення глутатіон-S-2,4-динітробензолу у реакції відновленого глутатіону 3 1-хлор-2,4-динітробензолом [8].

Реактиви: 0,1 М калій-фосфатний буфер $\mathrm{pH}-6,5 ; 2$ мМ відновленого глутатіону, на якому виготовляють extempore (6 $\mathrm{m}^{2}$ на 10,0 мл $\mathrm{H}_{2} \mathrm{O}$ ); абсолютний метанол; 2 мМ розчин 1 хлор-2,4-динітробензолу (10 мг розчинити в 1 мл метанолу + 23 мл 0,1 М фосфатного буферу).

Хід визначення. Виготовляють гемолізат: 0,5 мл цільної крови тричі промивають 10 мл ізотонічного розчину натрію хлориду та центрифугують протягом 10 хв. 3 швидкістю обертання 3000 об./хв. Отримують еритроцитарну масу яку для проведення дослідження розводять водою 1:10.

Реакцію проводять у кюветі спектрофотометра, до якої додають 1,5 мл розчину глутатіону 2 мМ та 0,1 мл гемолізату. Реакцію запускають 1,5 мл 0,2 мМ розчином 1-хлор-2,4динітробензолу.

Контроль: замість гемолізату вносять 0,1 мл $\mathrm{H}_{2} \mathrm{O}$.

\section{Маркери оксидативного стресу у дітей-мешканців РЗТ і дітей з родин вимушених переселенців із зони збройного конфлікту на південному сході України $(X \pm m)$}

\begin{tabular}{|l|c|c|c|}
\hline \multicolumn{1}{|c|}{ Показник } & І група & II група & $\begin{array}{c}\text { Контрольна } \\
\text { група }\end{array}$ \\
\hline $\begin{array}{l}\text { ТБК - активні продукти ПОЛ } \\
\text { (МДА), нМоль/мл }\end{array}$ & $3,96 \pm 0,25^{\star}$ & $3,84 \pm 0,31$ & $3,22 \pm 0,24$ \\
\hline $\begin{array}{l}\text { Супероксиддисмутаза, } \\
\text { ум.од./мгНb }\end{array}$ & $3,31^{\star} \pm 0,22$ & $3,39^{\star} \pm 0,24$ & $4,37 \pm 0,31$ \\
\hline Каталаза, мкМоль/мгНь х хв. & $2061^{\star} \pm 60,3$ & $1904 \pm 78,2$ & $1820 \pm 43,6$ \\
\hline $\begin{array}{l}\text { Глутатіонтрансфераза, } \\
\text { мМоль/хв. х мл }\end{array}$ & $2,60^{\star} \pm 0,10$ & $2,49 \pm 0,18$ & $2,18 \pm 0,14$ \\
\hline $\begin{array}{l}\text { Глутатіонпероксидаза, } \\
\text { мМоль/мгНь х хв. }\end{array}$ & $328^{\star} \pm 25,6$ & $346^{\star} \pm 31,2$ & $154 \pm 22,1$ \\
\hline
\end{tabular}

Примітка: * - достовірність різниці показників відносно контрольної групи $(p<0,05)$. 
підвищення порівняно з показником контрольної групи $(3,22 \pm 0,24)$ нМоль/мл, проте не сягав статистично значимого рівня ( $p>0,05)$.

Оцінка стану антиоксидантного захисту у дітей II групи показала, що активність глутатіонтрансферази мала тенденцію до підвищення порівняно 3 контролем $(2,49 \pm 0,18)$ мМоль/хв. х мл і $(2,18 \pm 0,14)$ мМоль/хв. х мл, $р>0,05$. Активність глутатіонпероксидази у дітей II групи становила $(3463,12)$ мМоль/мгНb х хв. і була суттєво вищою порівняно з показником контрольної групи $(154 \pm 22,1)$ мМоль/мгНb $x$ XB, $p<0,05$.

Активність супероксиддисмутази була нижчою за показник контролю - $(3,39 \pm 0,24)$ ум. од./мг $\mathrm{Hb}$ і $(4,37 \pm 0,31)$ ум. од./мгНb, p<0,05. Активність каталази становила (1904+ $78,2)$ мкМоль/мгНb x хв. і мала тенденцію до підвищення порівняно з аналогічним показником контрольної групи $(1820 \pm 43,6)$ мкМоль/мгНb х Хв., $p>0,05$, проте різниця не сягала статистично значимого рівня.

Отже, у дітей обох груп спостерігався дисбаланс у системі ПОЛ - АОЗ, більш виражений у дітей-мешканців радіоактивно забруднених територій.

Отримані результати досліджень можна пояснити, спираючись на сучасні наукові дані про функціонування ферментативної ланки АОЗ [9-11]. Найважливішими антиоксидантними ферментами $€$ супероксиддисмутаза, каталаза та ферменти групи глутатіону (глутатіонпероксидаза, глутатіонредуктаза, глутатіонтрансфераза), які впливають на початкову стадію вільнорадикалього процесу, регулюючи вміст активних форм кисню. 3 них першою проявляється активність супероксиддисмутази. Це єдиний відомий фермент, субстратом якого $€$ радикали.

Супероксиддисмутаза перетворює супероксидні аніонрадикали на молекулярний кисень та перекис водню, яка руйнується ферментами каталазою та глутатіонпероксидазою, що обриває ланцюг вільнорадикального окислення. Доведено, що термін життя різних клітин організму людини залежить від вмісту у них супероксиддисмутази: чим більше її кількість, тим довше живуть клітини.

Можна припустити, що за тривалої підвищеної активності вільнорадикальних процесів може настати зменшення вмісту у клітинах цього ферменту внаслідок його підвищених витрат на антиоксидантний захист $з$ подальшим пригніченням антиоксидантної ефективності [9].

Як вказано вище, каталаза нейтралізує перекис водню до води і водню. Глутатіонпероксидаза, субстратом якої $€$ відновлений глутатіон, нейтралізує в організмі гідроперекиси. Глутатіонредуктаза, субстратом для роботи якої $є$ окислений глутатіон, переводить останній у відновлений $[9,10]$.

Основна функція глутатіонтрансферази - захист клітин від ксенобіотиків і продуктів перекисного окислення за допомогою їх відновлення, приєднання до субстрату молекули глутатіону або нуклеофільного заміщення гідрофобних груп. Цей фермент кон'югує відновлений глутатіон з токсичними продуктами і тим самим сприяє їх виведенню із організму [11].

Підвищення концентрації каталази та ферментів групи глутатіону свідчить про надлишок перекису водню та активних форм кисню і підтверджує інтенсифікацію процесів вільнорадикального окислення [9, 10].

Отримані результати дослідження маркерів оксидативного стресу у дітей, які зазнали дії стресових чинників радіаційного та психогенного походження, можуть свідчити про інтенсифікацію процесів вільнорадикального окислення в організмі, на що вказують підвищення або тенденція до підвищення вмісту продуктів ПОЛ у сироватці крови, підвищення або тенденція до підвищення активності антиоксидантів - каталази, ферментів групи глутатіону. Зменшення активності супероксиддисмутази може вказувати на зни- 
ження антиоксидантної ефективності $[9,10]$.

\section{Висновки}

1. У дітей-мешканців РЗТ і дітей, переміщених із зони збройного конфлікту, мав місце дисбаланс у системі ПОЛ - АОЗ, більш виражений у дітей-мешканців РЗТ.

2. У дітей-мешканців РЗТ порівняно 3 контролем спостерігалося підвищення вмісту у сироватці крови кінцевих продуктів ПОЛ, які реагують з тіобарбітуровою кислотою; зміни активності ферментів-антиоксидантів: зниження активності супероксиддисмутази, підвищення активності каталази, глутатіонпероксидази, глутатіонтрансферази.

3. У дітей-переселенців із зони збройного конфлікту зміни показників інтенсивності процесів ПОЛ і активності ферментів системи антиоксидантного захисту мали односпрямований характер, проте були менш вираженими порівняно $з$ контролем, ніж у дітеймешканців РЗТ.

ЛІТЕРАТУРА

1. Степанова Є.І., Базика Д.А., Позниш В.А., Ярошенко Ж.С., Студеникина О.М., Вдовенко В.Ю., Леонович О.С., Гриценко Т.А. Медико-психологічні проблеми дітей, переміщених із зони АTO. Медичне забезпечення антитерористичної операції. Науково-організаційні та медико-соціальні аспекти: зб. наук. праць. К., 2016. C. 193-199.

2. Позниш В.А. Застосування АРТ-терапії у лікувальному процесі дітей $з$ психосоматичною патологією, переміщених із зони проведення ATO, та дітей-мешканців радіоактивно забруднених територій. Журнал НАМН України. 2018. Спеціальний випуск. С. 83-84.

3. Гороть І.В., Ткаченко М.М. Особливості ультраструктурної організації і метаболізму реактивних форм кисню та азоту у серцево-судинній системі за постійної дії іонізуючого випромінювання у низьких дозах. Проблеми радіаційної медицини та радіобіології. 2017. Вип. 22. C. 184-201.
4. Победьонна Г.П. Роль змін показників перекисного окислення ліпідів, ферментів антиоксидантного захисту та метаболітів оксиду азоту у формуванні системного окислювального стресу у хворих 3 загостренням бронхіальної астми. Лік. справа (Врач. дело). 2005. № 5/6. С. 36-40. 5. Трегубова И.А.,

Косолапов В.А., Спасов А.А. Антиоксиданты: современное состояние и перспективы. Успехи физиологических наук. 2012. Т. 43, № 1. С. 75-94. 6. Чанчаева Е.А.,

Айзман Р.И., Герасев А.Д.

Современное представление об антиоксидантной системе организма человека.

Экологическая физиология.

Экология человека. 2013.

№ 7. С. 50-57.

7. Методи оцінки вільнорадикального окислення та стану антиоксидантної системи організму у клінічній практиці: методичні рекомендації / Науковий центр радіаційної медицини АМН України.

Київ, 2007. 23 с.

8. Медицинские лабораторные технологии: справочник / под ред. А.М. Карпищенко. СПб: Интермедика, 1992. Т. 2. C. 23-24.

9. Фархутдинова Л.М.

Окислительный стресс.

История вопроса. Вестник Академии наук РБ. 2015. Т. 20, № 1. С. 42-49.

10. Луцкий М.А., Земсков А.М., Разуваева В.В., Рушникова Ю.П., Карпова О.Ю. Окислительный стресс - індикатор метаболических нарушений в патогенезе мозгового инсульта.

Журнал неврологии и психиатрии. 2016. № 8, вып. 2. С. 24-29.

11. Кочерга 3.Р., Ерстенюк Г.М. Особливості активності ферментів глутатіонової системи у новонароджених 3 затримкою внутрішньоутробного розвитку плода.

Одеський медичний журнал.

2014. Т. 146, № 6. С. 51-54. REFERENCES

1. Stepanova Ye.I., Bazyka D.A., Poznysh V.A., Yaroshenko Zh.S., Studenikina O.M.,

Vdovenko V.Yu., Leonovych O.S. and Hrytsenko T.A. Medykopsykholohichni problemy ditei, peremishchenykh iz zony ATO [Medico-Psychological Problems of the Children Displaced from the ATO Zone.] In : Medychne zabezpechenni aantyterorystychnoi operatsii. Naukovo-orhanizatsiini ta medyko-sotsialni aspekty: zb. nauk. Prats. [Medical Support for Anti-Terrorist Operation. Scientific-and-Organizational and Medico-Social Aspects : Coll. Sci. Works.]. Kyiv ; 2016 : 193-199 (in Ukrainian).

2. Poznysh V.A. Zhurnal

NAMN Ukrainy. 2018 ; Special

Iss. : 83-84 (in Ukrainian).

3. Horot I.V. and Tkachen-

ko M.M. Problems of Radiation

Medicine and Radiobiology.

2017 ; 22 : 184-201 (in

Ukrainian).

4. Pobedionna H.P. Likarska sprava (Vrachebnoe delo). 2005 ; 5/6: 36-40 (in Ukrainian).

5. Tregubova I.A., Kosolapov V.A. and Spasov A.A. Uspekhi fiziologicheskikh nauk. 2012 ; 43 (1) : 75-94 (in Russian).

6. Chanchaeva E.A.

Aizman R.I. and Gerasev A.D.

Ekologicheskaya fiziologiya.

Ekologiya cheloveka. 2013 ; 7 : 50-57 (in Russian).

7. Research Center for Radiation Medicine. Metody otsinky vilnoradykalnoho okyslennia ta stanu antyoksydantnoi systemy orhanizmu u klinichnii praktytsi: metodychni rekomendatsii [Methods of the Evaluation of Free Radical

Oxidation and State of

Antioxidant System of the Organism in Clinical Practice :

Methodical Recommendations].

Kyiv ; 2007 : 23 p. (in

Ukrainian).

8. Karpishchenko A.M. (ed.)

[Medical Laboratory

Technologies: Reference Book]. Sankt-Peterburg : Intermedika ; 1992 ; 2 : 23-24 (in Russian).

9. Farkhutdinova L.M. Vestnik Akademii Nauk RB. 2015 ; 20 (1) : 42-49 (in Russian).

10. Lutskiy M.A., Zemskov A.M., Razuvaeva V.V., Lushnikova Yu.P. and Karpova O.Yu. Zhurnal nevrologii I psikhiatrii. S.S. Korsakova. 2016 ; 8 (2) ; 24-29 (in Russian).

11. Kocherha Z.P. and Ersteniuk H.M. Odeskyi medychnyi zhurnal. 2014 ; 146 (6) : 51-54 (in Ukrainian).

Надійшла до редакції 12.07.2019 